\title{
A CONTINENTAL LAWYER IN AN AMERICAN LAW SCHOOL: TRIALS AND TRIBULATIONS OF ADJUSTMENT *
}

\author{
Mirjan DamašKa $\dagger$ \\ Nous ne nous sommes pas faits, \\ comme des notes de musique les \\ uns pour les autres parce que \\ différents?
}

André Maurois

When you pause to consider the problem indicated by the title, your first reaction may be that it is too general to be meaningful. Is there any justification for using the broad label "Continental lawyer"? Can we lump together European lawyers from various countries, east and west? Is the topic not inextricably bound up with the great controversies raging over the existence, distinguishing characteristics, and interrelationships of various families of law? Is there any consensus on common features of legal education here or abroad? In sum, are there not so many qualifications on anything one may choose to say on this subject that the total view is lost? Even with all these difficulties in mind, the more I reflect on the problem and exchange experiences with people who have gone through the same process of adjustment, the more $I$ become persuaded that a number of significant points can be made on the general theme suggested in the title. Notwithstanding the great differences existing among them-and in spite of orientation programs-most lawyers trained in Continental law schools face rather similar difficulties in approaching the study of law in an American educational institution.

I shall impose arbitrary limitations on my discussion. As I proceed it will become increasingly obvious that there exists a close and probably reversible relationship between the nature of a legal system and patterns of legal education. However, not all difficulties in adjustment result from problems of acclimation to an alien legal system.

* Adapted from a talk given to the graduate students at the University of Pennsylvania Law School in March 1968.

† Visiting Professor of Comparative Law 1966-68, University of Pennsylvania. Professor of Law, University of Zagreb (Yugoslavia). LL.B. 1955, University of Zagreb (Yugoslavia). D.J. 1960, University of Ljubljana (Yugoslavia). Bicentennial Fellow 1961, University of Pennsylvania. 
Some stem from exposure to different educational methods. Yet the latter will be dealt with only sparingly, through comments often relegated to footnotes. I will not attempt any explanation of the problems of adjustment in terms of the divergent histories of legal education on the Continent and in Anglo-Saxon countries. But in spite of these limitations I can achieve clarity only at the price of substantial simplification. It would seem to me that, in this general area, efforts to present minor offsetting tendencies only too often result in loss of clear vision. It takes a Breughelian talent I do not possess to deal with all the minutiae and still preserve the clear simplicity of the tableau. I can only hope that simplification will not be carried to the point of distortion and that those who have gone through all the pain and travail of adjustment will still be able to recognize, somewhat caricatured, bits and pieces of their own experience.

A good point of departure seems to me to be a description of what is imparted to a law student in the course of his legal education in a European university. Thus, at the very outset I will offer a broad generalization. From there I shall go on to give a summary account of what a finished product of a Continental law school expects to derive from his exposure to American legal education. Here, you will realize that $I$ am dealing mostly with the expectations of those with an academic, rather than a practitioner's, interest in American law. In the third part of my presentation I shall catalogue the more important difficulties arising out of the clash between expectations and reality. I will conclude by venturing a few suggestions for ameliorating the adjustment problems faced by the typical Continental law student.

\section{European Legal Education}

As in this country, so in European countries there is a great deal of controversy over the aims of legal education and the role universities should play in it. Traditional ideas on curricula as well as methods of instruction are increasingly questioned; new ideas are discussed and, in some countries, experimented with. Yet notwithstanding these winds of change and the considerable differences that exist among various European countries, fluctuation and diversity fade away when viewed from this side of the Atlantic. A distinctive Continental mos iura docendi still seems to exist. As I see it, one can distill the essential ingredients of Continental law school experience. This essence involves exposure to what I will call the grammar of law, a panoramic view of the most important fields of law, and some initiation into the patterns of legal reasoning. These three essential ingredients must be treated separately although they are imparted simultaneously. 


\section{The Grammar of Law}

While it would be false to imply that grammar is completely absent from American law, the fact remains that there exists no real counterpart to the Continental grammar of law. ${ }^{1}$ The difference is perhaps in the degree of refinement and importance of grammar in the two systems.

In order to gain an understanding of Continental legal grammar, Americans should imagine lawyers of an analytical turn of mind à la Hohfeld at work for a long time, studying the law as it emerged from legal practice. Americans should further imagine that both the analysts' dissection of law and their generalizations were generally accepted by the legal profession. Let me pursue this hypothesis with specific examples and suggest what the consequences might be for American law.

Many rather amorphous American legal concepts would be subjected to rigorous analysis. An illustration is the concept of jurisdiction with its bewildering number of meanings. Words and phrases like "property," "standing to sue," "security," and "mens rea" also come to mind. In the process of analysis the twilight zone of the concepts would be somewhat reduced, sub-concepts isolated and separately labeled. A richer and more precise legal terminology would appear. Movement would also proceed in the opposite direction, that is, toward the creation of more general, sometimes almost cathedrallike concepts. For example, inquiry into what contracts, conveyances and wills have in common would probably result in something similar to the Continental concept of legal transaction (Rechtsgeschäft, negozio giuridico). These newly created, broad concepts would become accepted as elements of standard legal terminology. Study would then proceed to the relationships between such legal concepts. Questions would be raised about the relationship of "jurisdictional" to "procedural" issues, of "mistake" to "mens rea." Inquiry into relationships between concepts would be linked to an investigation into the nature or essence of concepts. For example, what is the nature of "arbitration," or of "pleadings" and "stipulations" in criminal procedure? Pursuit of what is common to the decisional law of seemingly unrelated areas would be conducive to the creation of broader rules

1 The expression "grammar of law" has been borrowed from T. Holland, THE ElEMENTS of JURISPRUDENCE 7 (5th ed. 1895). This metaphoric term is not used on the Continent. Instead, labels such as "legal science" or "doctrine" are found. (For an American reference to "scientific legal terminology," see Guaranty Trust Co. v. York, 326 U.S. 99, 109 (1945)). However, I decided to use it because of its vividness and because it suggests comparison with linguistics. Is it not true that languages like French, German or Russian have more grammar and much more standardization of proper usage than American English? While grammar in this country seems mostly descriptive, is not grammar prescriptive in most European languages? 
(e.g., on misreprentation in conveyances, contracts, and so forth) and even to the development of principles (e.g., principles of procedure). ${ }^{2}$ Almost imperceptibly an urge to establish a rigid network of classification would develop; for example, the question whether we should separate real and personal property would arise. Thus, step by step, the conceptual digestion of the law would result in a network of precise interrelated concepts, broad principles and classificatory ideas. This network is the grammar of law.

Most American lawyers will be sceptical at best of the usefulness of this curious conceptual structure. Some, conversant with the latest trends in jurisprudential thinking abroad, will point out not only that analytical work has fallen into disrepute in this country, but that the conceptualistic approach seems to be coming under increasing attack in Europe as well. It is my belief, however, that even those Continentals to whom conceptualistic jurisprudence is a bete noire would be taken aback at the paucity of conceptual digestion in most areas of American law. Contracts and especially criminal law would be glaring examples. I submit that even Continental "doubting Thomases," if invited to deal with practical legal problems, would rally to the support of legal grammar, on the condition that it remain-just as in language-in an ancillary role. Even anti-conceptualists would, I believe, concur in the traditional justifications advanced by Continentals in defense of their legal grammar.

Let me quickly sketch these often overlapping justifications. In the first place, it is claimed that a well developed legal grammar results in economy of thought. The concepts in such a grammar can be used independently of specific legal rules, just as elements in an algebraic system, and with all the advantages of algebra over arithmetic. Pursuing mathematical analogies, one can say that the urge to generalize résults in factoring out common features, thus leading to simplification. A great many heretofore unrelated legal rules can be seen as offshoots of a single more general rule or principle.

A related advantage attributed to legal grammar is clarity of vision, sometimes expressed by the old Latin tag praxis sine theoria caecus in via. Broad interrelated concepts facilitate awareness of the ramifications of hypothetical legal situations, notably contemplated changes in the law. Thus law can more easily be tested by logic. It is further

2 The work of legal theorists does not stop here. Insight into what they do further in a specific field may be gained from Schmidt, Von Sinn und Notwendigkeit wissenschaftlicher Behandlung des Strafprozessrechts, 65 ZEITSCHRIFT FÜR DIE GESAMTE STRAFRECHTSWISSENSCHAFT 161 (1953). Of late it has become fashionable in some countries to conceive of certain legal concepts and classifications as ontological entities. See Dre Ontologische Begründung des Rechts (A. Kaufmann ed. 1965). However, these much more cosmic questions do not affect the outlook of the ordinary young lawyer, the typical finished product of a Continental law school. 
believed that profound analysis of the law sometimes fosters a sense of the proper order of analysis. ${ }^{3}$ This in turn goes a long way towards shielding the average legal mind from confusion. Finally, it is believed that legal grammar represents an essential prerequisite for the satisfactory drafting of comprehensive legislation ${ }^{4}$ and the successful ordering of judge-made law. ${ }^{5}$

The importance attached to legal grammar explains why initiation into it represents one of the minimal requirements of legal education in Continental law schools. Even a casual glance at any student manual will immediately reveal the extent to which "grammatical" considerations dictate the organization and presentation of the body of law.

\section{The Panoramic View}

In addition to an initiation into the grammar of law, the Continental student is also offered what would, to an American lawyer, appear to be a panoramic presentation of the most important fields of law. This comprehensive view of the whole is considered to be of utmost importance. It is feared that if the young lawyer fails to perceive the great contours of private and public law in school, he will seldom acquire an overview later in practice. Entangled in the jungle of practical problems, he will be deprived of the guidance that comes from an awareness of the totality of law in his particular field.

The way in which the panoramic view is offered would be rather startling to an American lawyer. Even aside from discussion of the highly abstract legal issues closely connected with the Continental legal grammar, ${ }^{6}$ discourse proceeds most of the time on a level that seems much too abstract to the American legal mind. Statutory or code provisions are systematically presented on a level which seems to

3 Proper order, of course, imposes limitations on levels of analysis. An excellent example of the proper order of analysis imposed by analytical work can be found in Ryu \& Silving, Toward a Rational System of Criminal Law, 32 REVISTA JURIDICA DE LA UNIVERSIDAD DE PORTo RICo 119, 126-37 (1963). Another illustrative example of the self-imposed order of analysis can be found in the manipulation of the ordre public device in Continental conflict of laws. See R. Schlesinger, Comparatrve Law Cases -Texi-Materials 470-76 (2d ed. 1959).

4 Legal grammar may offer a basis for logical rather than alphabetical arrangement of subject-matter. Further, it is possible that only legal grammar of some sophistication can provide a basis for avoiding antinomies and omissions in interrelated provisions. Finally, the wealth of long-range and intermediate concepts provides statutory language with the necessary breadth.

5 For example, French administrative law, created by the Conseil d'Etat, has been very neatly ordered by French legal scholars.

C Those who feel a need for an illustration should take a look at any Continental text; such treatises usually duplicate in manual form the professor's oral presentation. Perhaps as good an example as any in English translation is S. DANDo, JAPANESE CRIMINAL PRocedure (1965). Examples of topics connected with the Continental grammar are "the essential nature of the law of criminal procedure," $i d$. at 20 ; "basic concepts," id. at 125 ; "general elements of procedural acts," $i d$. at 156. 
provide only vague guidelines for the solution of actual cases. Occasional references to actual cases will almost invariably be made in generalized form. The legal problems in a case will be treated in the abstract, as illustrations of how the court evolved legal rules, adapted to the solution of the case, from the more general ones found in the code or statute. When on a rare occasion the discussion does descend to the level of particular facts, it will be abruptly cut off by the remark that a questio facti is involved which does not merit further analysis. ${ }^{7}$ The American lawyer would thus discover that, more often than not, where his interest really begins the law teacher's seems to end. A related and similar source of distress to an American would be the paucity of references to the meaning of legal rules in practical operation. He would be shocked to find that as much time is devoted to analysis of legal problems of only academic interest as to problems commonly confronting the courts. Almost never would he find discussion of the influence of procedural considerations on substantive issues. ${ }^{8} \mathrm{He}$ would be positively annoyed by the method of instruction that still prevails in Continental law schools, with formal and not infrequently somewhat soporific lectures. Faced with professorial assertion on the basis of what to him seemed vague and inconclusive authorities, he would be tempted to think that the teacher was getting his law out of his head. I believe he would soon decide that he could make equally good (or bad) use of his time by reading lectures in the form of scripta, or by studying the professor's manual or treatise.

\section{Patterns of Legal Reasoning}

By American standards, Continental law schools give very little training in "how to think like a lawyer." Stimulation of students to participate in problem solving (on the Continental level of discourse), while not unknown, is comparatively insignificant. This is not to say that patterns of thinking are not implanted in students, if only through

7 "Questio facti" is a misnomer and should not be confused with factual issues. It is a legal issue, but so closely intertwined with the factual circumstances of specific cases that it is of little academic interest to a civilian mind. For instance, what constitutes probable cause for arrest, being a mere questio facti, would not be discussed in class.

8 Hence the suprise of a Continental who, having explained a refined civilian distinction to his American colleague, is asked: "How do you go about establishing the distinction in court?"

9 Whether the professor's talents are put to the best use in the traditional formal lecture is open to question even in Continental minds. The famous 17th century German lawyer Benedict Carpzov is alleged to have hired a singer from the Leipzig opera to read Carpzov's Vorlestungen to his students. It is not at all unlikely-horresco referens-that the singer was far more stimulating than the professor. However, many Continental lawyers of great reputation and comparative experience advocate the traditional lecture method. See, e.g., Tunc \& Tunc, Le droit des Etats-Unis d'Amerique, in SOURCES ET TECHNIQUES 317 (1955). 
exposure to the style of thinking of the faculty. Let me present a very cursory sketch of this style, for it is important for my purposes. ${ }^{10}$ Very characteristic is an urge to relate particular problems to a whole array of rules, principles and "grammatical" ideas. Logical consistency within the array assumes a very great importance. Seldom does one find the feeling that discussion of rules apart from judicial application is somewhat vacuous. There is a significant lack of the argumentative approach towards the law which permeates the atmosphere of law schools in this country. The moving spirit of analysis is not the desire to find the best argument for a proposition, but rather the quest for the "right" answer to the problem at hand. Conspicuous by its absence is the intertwining of legal and nonlegal arguments so common here. ${ }^{11}$

Comparatively speaking there is also very little preparation in Continental law schools for the practical problems awaiting the student (handling of sources, legal writing, and the like). But even though vocationally oriented education represents an inferior intellectual tradition to the Continental lawyer, I do not think that a typical Continental law professor is insensitive to the needs of practical training. $\mathrm{He}$ would agree that a full-fledged lawyer needs practical as well as theoretical preparation. Theoria sine praxis rota sine axis. However, he will probably argue that theoretical and practical preparation cannot both be offered in school, and that a choice of priorities must be made. Since in the Continental scheme of things theoretical preparation and a grasp of the whole must precede exposure to the complexities of

10 In drawing a cursory sketch I cannot avoid the danger of making this style of thinking look like the pure conceptualistic jurisprudence which, as I have pointed out, has been largely rejected in Europe. It is also possible that even a much more precise presentation of Continental reasoning would still appear unadulterated conceptualism to most Americans, while the Continental would classify the reasoning as being at a safe distance from Begriff sjurisprudeutz. I draw some consolation from the fact that much of American legal reasoning would appear to Continentals to be an exercise in Freirechtslehre. Since the identification of Continental reasoning with excessive conceptualism seems unavoidable, I do not think much further damage will be done if I suggest to those looking for a short example Max Rheinstein's illustration in his Introduction to M. WEBER, LAW IN ECONOMY AND SOCIETY xliii (M. Rheinstein ed. 1954). Those who want to pursue the matter should compare Learned Hand's reasoning in Wood \& Selick, Inc. v. Compagnie Generale Transatlantique, 43 F.2d 941 (2d Cir. 1930) with the civilian treatment of the same case by Oscar Morineau in Rights and Remedies, 8 AMr. J. CoMp. L. 263 (1959). Morineau's handling of concepts like "right of action" and "legal remedy" in his pursuit of a "scientific solution" is as good an example as any of what I mean to convey in the text.

11 A casual look at law school curricula in European countries will reveal that much time is devoted to economics, sociology and similar disciplines. Yet after my experience in this country I do not think there is much functional integration of various interdisciplinary insights on the Continent. A Brandeis brief would be a great surprise to Continentals. Merryman's observation on cultural agnosticism in the Italian style of legal thinking, as well as many other of his lucid observations, hold true of the Continental style in general. See Merryman, The Italian Style I: Doctrine, 18 STAN. L. REv. 39, 52 (1965). 
practice, precedence is given to rendering instruction in the grammar of law and in the grand contours of most important fields of law. It is upon graduation and during the internship period preceding the bar and bench examinations that the student receives a rigorous practical training in how to find the law and write about it.

The three components may now be drawn together. If a Continental student has acquired some mastery of legal grammar, if he has learned the substantive rules as presented in the panoramic view, and if he has gained some grasp of the style of thinking described, he is a successful product of Continental legal education on the university level.

\section{The Expectations of a Continental Lawyer}

When the Continental law school graduate enters practice, the neatness, simplicity, and purity of the vision of the law imparted to him in school will be somewhat marred. Yet, even after extended legal practice most of the attitudes shaped in school, somewhat modified, will still influence his perception of law. Of course, if he is fresh from law school-as are many foreigners in American law schools-the impact of his legal education will be undiluted in its strength. Some features of the young lawyer's outlook should concern us here.

$\mathrm{He}$ will tend to associate at least modern domestic law with a more or less closed and orderly system. He will assume that precise terminology, conceptual specificity, and other elements of the Continental legal grammar are indispensable tools for mature legal analysis. Sensitivity toward logical consistency over relatively wide areas will appear to him to be an attribute of a good lawyer. It will seem natural to be able to gain a panoramic view of legal fields. He will believe that legal discourse of real importance proceeds on the level of rules he is familiar with, and that emphasis on factual questions and too much concern about justice in a given case betray a non-technical, layman's approach-what Max Weber called "khadi justice." 12 For him the primary purpose of legal discussion-at least in the academic milieuwill be the quest for right answers rather than partisan arguments.

What does a lawyer with a more or less pronounced outlook of this sort expect to derive from the study of law in an American law school? I think it is realistic to assume that the lawyer's interest will be focused on a given field of law in his civilian classificatory scheme. For example, he will be interested in what to him is "property law" (law of things) and therein "ownership" or "real actions," or in what

$12 \mathrm{M}$. WEBER, supra note 10 , at 213 . 
to him is "administrative law" and therein "police power." Very high on his list of priorities will be the desire to gain an understanding of the American conceptual technique in law, which, he is told, differs from his own. He will, for instance, want to know how the American concept of jurisdiction relates to his concept of jurisdiction. What exactly is waiver? Can estoppel be associated with venire contra factum proprium? Is there a functional counterpart for ius cogens and ius dispositivum, for "ordinary" and "extraordinary" legal remedies, causa or "unlawfulness" (Rechtszeridrigkeit) ? ${ }^{13}$ In sum, he will expect to learn the conversion formulae whereby his indispensable tools of analysis may be made applicable in the context of foreign (American) law. I submit that the desire for conceptual counterparts represents a pressing cognitive need for most lawyers coming from the Continent, even if their ultimate aim is to compare the fulfillment of social needs through legal devices.

In the field of his choice the student will also expect to gain a panoramic view corresponding to the one he possesses of his discipline in his native system. For example, one interested in procedural problems and more specifically in "legal remedies against judgments" will expect to gain a comprehensive view of American ideas on direct and collateral attack. Or, to choose a more dramatic example, a student of criminal law would want to gain a synthetic view of the "general part of American substantive criminal law." $\mathrm{He}$ will assume that this preliminary job of getting the feel for the grand contours will not take much time or effort. There will be, he expects, manuals or other sources that will synthesize the kinds of problems that are, in his system, always discussed in connection with "legal remedies" or problems of the "general part of criminal law." He will expect that, having obtained the general orientation in his field, he can then study more closely what to him is already a quite specific problem, such as coram nobis in post-conviction remedies, or specific intent in the "general part." If he has a keen mind, he will expect to pursue his study even further, to more limited problems which will resemble the scope of a typical American law review article. This gradual descent from the general to the specific will, I submit, be another cognitive need of the Continental. He will want first to inspect the forest, the trees, then turn to branches and twigs. Specific problems of litigation on the level of his questiones facti will be even further down the line. But before he gets engrossed in these problems, he will feel he must satisfy his more pressing cognitive needs.

13 The analogue of the last concept will be of interest primarily to those Continentals whose legal systems were subjected to the influence of German scholars. Need I point out that there is no concept of Rechtsweidrigkeit in this country? 


\section{The Clash Between Expectation and Reality}

If there is a measure of truth in the preceding description of expectations, the problems faced by a Continental lawyer attempting to adjust to a typical American law school are not too difficult to fathom. I cannot hope to discuss them all, so I shall limit myself to the most pressing.

There will be a stumbling block at the very first step. The foreigner will immediately discover that his specialty has no real counterpart in the American scheme of divisions of law. The student with an interest in property law will vainly seek "real actions" in American writing on property. On the other hand he will find matters inserted in the law of property that seem to be taken out of their natural habitat. Thus he will find the lease treated as a "real right" while its proper situs, to his mind, is in the law of obligations. To the possible chagrin of a privatist, taxation and zoning problems will also be incorporated into property books.

Some will say that there is nothing undesirable about this initial problem, for the student is just learning his first lesson in comparative legal studies, namely, to discard domestic boundaries of law. Many students, however, for all their orientation programs, spend a disproportionate amount of time chasing the topic of their interest all over the American legal landscape.

Sooner or later they will assemble what to them is comparable matter and select the right law school courses. Quite naturally they will attempt to gain the panoramic view described above. It is at this point that they will be in real trouble: courses will be of no help to them in this respect. Even if instruction is not limited to the Socratic discussion of cases, Continental students will still have the feeling of being offered an assembly of miniscule fragments when they want a synthesis. ${ }^{14}$ They will then resort to hornbooks and similar writings designed for those who, unencumbered by an alien legal training, seek basic information in an American branch of law. These books will seldom be of help. Their organization, unspoken assumptions, and general level of discussion will present to a Continental legal mind more questions than answers. Ever present will be the need for conversion formulae. If the students seek help from their instructor, he will explain that the view of the whole which they seek cannot be given even in a single jurisdiction, much less nationally. At least some instructors will be sceptical that such an instantaneous

14 Continentals often wonder how students can be capable of discussing difficult cases and intricate problems-Grenzsituationen-without preparation in more elementary matters and settled areas of law. But as I cautioned at the outset, I cannot go into the difficulties stemming from the Socratic method. 
snapshot of the law can be offered at all, for law is living, constantly growing. To this the student will reply that he can see the twigs and branches of the system changing all the time, but that he would have expected the trees and the forest to be relatively stable. And, he will add, it is precisely the latter two that he is interested in at the moment. Not infrequently, in the absence of comparativists, there will be a difficulty in further communication at this point.

After exposure to the finely shaded rigidities of the Continental legal grammar, the student will discover that it has virtually no analogue in American law, and that very little importance is attached to the conceptual digestion of the law. He will find that definitions, so important to his mind, are viewed with a scepticism reminiscent of classical Roman lawyers.

In the meantime the Continental student will diligently go on reading cases and statutes in pursuit of the answers to problems that keep multiplying. Leaving aside the troubles he will experience with statutes and statutory compilations completely different from those with which he is accustomed, ${ }^{15}$ let me quickly sketch what I think will be his typical attitude in reading cases. Many of his problems stem from this attitude. After reading a number of cases, he will feel an urge to rise above the bewildering richness of factual detail and distill legal propositions therefrom. He will then attempt to relate these propositions to newly distilled ones from an additional group of cases, and somehow peg all of them to a larger whole. Only in this fashion does he hope to come out with (what he would call) legal rules rather than mere answers to questiones facti or examples of the application of rules. More often than not, his structure collapses in the bewildering mass of cases seemingly or actually contradictory. ${ }^{16}$

15 Of these difficulties arising from differences in statutes, four seem to me to be most common. First, the Continental student feels a lack of vision resulting from frequent American classification in alphabetical sequence rather than in some kind of logical order. Second, the student is bewildered by regulation of miniscule detail, and by all the dangers such an approach entails. Third, he wonders whether the prolific use of near synonyms in the statutory language results in real or only apparent tautologies. For example, what is the difference between reversing and vacating a judgment? Last but not least, the Continental student approaches statutory interpretation in the civil law fashion, which is reminiscent of the ancient English "equity-of-the-statute" doctrine. And he is often at a loss as to the precise scope of authority granted to bodies charged with statutory compilation. Precise information on sources is of first importance to a Continental mind.

16 There are many additional difficulties which Continental lawyers must surmount in attempting to find the law in the reported cases, but considerations of brevity have limited discussion in the text to the most important one for my purposes. However, I should point out a related source of surprise to a civilian trained lawyer. He will be astonished at how many issues are unsettled in areas which to his mind should be firmly established. The fact that this unfinishedness in the law does not alarm the legal profession will be even more surprising. Perhaps an example is needed. In Warden v. Hayden, 387 U.S. 294 (1967), the Supreme Court finally rejected the "mere evidence rule" (a rule which, incidentally, was incredible to the European mind), but reserved the question whether certain evidentiary objects are "by their nature" pre- 
It is not improbable that at this point the Continental student will become so frustrated that he will seek solace in a discussion with his adviser on the openness of the system and on its fluidity. If his adviser happens to belong to the realist school of legal thought, he may attempt to help him with a little psychoanalysis à la Jerome Frank, and explain the student's longing for stability and certainty in terms of the immature child's need for infallible authority.

This brings me to problems of communication in legal discussion. Claiming no great discoveries, I can see at least four sources of diffculty. The first is produced by disparities in the level of discourse. As has been repeatedly intimated, the Continental tends to move on the level of abstract rules which to his American counterpart often seem to be only rather vague standards. ${ }^{17}$ In contrast, American legal discussion usually proceeds on the more concrete level of what a Continental would consider to be less significant questiones facti. Second, the strength of legal arguments differs substantially. Logical consistency over areas too wide for American taste is of very great importance to a Continental mind, which in turn remains closed to many specific arguments much higher on the American scale. ${ }^{18}$ In the third place, the Continental conceptual scheme imposes relatively rigid methods of analysis, while the non-grammatical American legal

cluded from being searched and seized. To a Continental lawyer it seems imperative that if such objects exist they should be enumerated, particularly in view of the exclusionary rule. The Continental would probably say that if the Court felt that it could not resort to judicial law-making as it did in the celebrated case of Miranda v. Arizona, 384 U.S. 436 (1966), then some sort of quick legislative action was needed. The attitude of postponing the settlement of important issues until the exigencies of some future case require it, and the resulting unfinishedness of the legal system are, I submit, sources of great frustration to the Continental lawyer studying American law.

17 For example, Perkins treats provisions of the Model Penal Code dealing with the insanity test as standards, too vague to be called rules. $R$. PERKINS, CRIMINal LAw 766 (1957). To a Continental lawyer the language of the Model Penal Code indicates a rule, not too broad in scope at all.

18 On the different role of logical arguments, see Tunc \& Tunc, supra note 9 , at 205,236 . The authors state that anything in French law which is not impervious to analytical attack will not remain law for long. This, I believe, holds true of other Continental systems as well. The unreceptivity of Continentals to pragmatic arguments in a related field is delightfully illustrated in A. RAPAPORT, OPERATIONAL PrILOSOPEY 113 (1965). I think the characterization is applicable pari ratione in law.

Perhaps I should add that some Continental arguments strike American lawyers as formalistic, almost pedantic. To an American, Continentals appear to be unduly disturbed by some merely ministerial problems or what at least some Americans might label empty rituals. For example, the Continental lawyer would be terribly disturbed because, in most jurisdictions, statutes can take effect without official publication. Pragmatic arguments about alternative routes of communication, or scepticism about the effectiveness of the publication would not be likely to persuade the Continental. Similarly the Continental would be intrigued about the status of a judgment attacked on "habeas corpus" after relief has been granted. If the judgment is not formally invalidated how can a new prosecution be instituted? That defendants are sometimes permitted to take an appeal before a final adverse judgment would strike the Continental as violative of elementary procedural ideas. Concern about the precise scope of authority granted to bodies charged with statutory compilation falls into the same category of Europeans' preoccupation with "minor technicalities." 
mind remains very flexible. ${ }^{19}$ Finally, the very goals of legal discussion frequently will not coincide. The Continental will seek the right solution; his counterpart will display a liberal agnosticism about "right" answers, coupled with a procedural outlook. He will be primarily concerned about good arguments for a case. ${ }^{20}$

We need not go any further. It should have become obvious that real acclimation to an American law school calls for much more than merely forgetting about traditional Continental boundaries of law. It seems to me that the student must be flexible enough to discard-in dealing with American law-a large part of what is essential to the formation of a successful Continental law student.

\section{A Move to Reconciliation}

If, as I hope, I have captured something of the difficulties a Continental lawyer experiences in adjusting to American law schools, the question arises whether something can be done about it. Some psychological help may come from the realization that one's problems are shared by others in his position. But I do not think this is the whole story. This belief gives me the temerity to make a number of observations on guidance in the adjustment process.

In his first steps the Continental lawyer must be under the wing of people with real understanding of his adjustment difficulties. This is so obvious that I must apologize for stating it if $I$ am wrong in believing that orientation programs are not sufficiently geared to Continental cognitive needs and often seem to be designed more to establish beachheads than to build bridges. There are many people in this country who are well equipped to counsel Continental lawyers facing adjustment problems, because they have themselves successfully undergone the difficult transformation from a Continental to an American legal mind. Even those who never really made the transition and are still somewhat uncomfortable in American law are still marvelous guides; those who can speak with the authority of failure have a lesson to teach. On the other hand, the most illustrious members of the American legal profession will not be of much help if

19 See note 3 supra.

20 The opinions which lawyers from different systems hold of one another-at least as long as better understanding is not achieved on a common project-are affected by the dissonance described in the text. A student who is outstanding by Continental standards may be considered somewhat diffuse, interested in vague generalities rather than actual litigation problems. In discussion he may be thought too conceptualistic and rigid, sometimes possibly pedantic. He will seem to be more interested in learning than in analysing and arguing. Often he will not be able to give "useful" information about his law. On the other hand, he will display an uncanny ability to provide the kind of orientative answers which could be given in this country only after long study, if at all. 
they lack the insight that comes from experience. A word may be in order here on the most promising candidates for easy adjustment. I believe that the more practical experience the Continental lawyer has, the less severe his adjustment problems will be. Law school graduates without any exposure to the practice of law will be in the most difficult situation. Continental scholarly types with academic interests in American law will face grave adjustment problems. ${ }^{21}$

As I see it, initial orientation must emphasize the field of law that happens to be the center of the Continental lawyer's interest. The occasional student with an undifferentiated interest in American law should be viewed with some suspicion. Of course, here we run into the problem of differences in divisions of law. Therefore, as soon as the foreigner's field of choice is known, he should be told which divisions of American law and which law school courses encompass the problems in which he is interested. It is not impossible that it will soon appear that the situs of the foreigner's interest is outside the boundaries of American law, and that courses dealing with his problem are taught in other departments of an American university. For example, some areas of European financial law would in America be treated under the rubric of economics or political science. The foreign lawyer must be saved the time he may lose tracing the problems in which he is interested through the perplexing divisions of American law and the wide variety of course offerings in American law schools. Comparative law literature dealing specifically with this problem is, unfortunately, rather scarce. ${ }^{22}$ Thus, more often than not the Continental lawyer cannot merely be assigned readings; he will have to rely on consultations with his guide.

Having learned where to find the legal problems he is interested in and which courses to take, the foreign lawyer will feel a pressing need for a panoramic view of the substantive rules in his field of choice. Due to the differences in the nature of the legal systems, there will be great limitations on what he can be offered in order to satisfy his intellectual needs. Discussions with his mentor on the difficulties of gaining a bird's eye view of American law in his specialty may, however, go a long way towards reducing adjustment problems. More-

21 Perhaps this holds true of visiting professors as well. I have often thought that to many Americans a lawyer of the German "repetitor" type would be a much more interesting conversational partner than the typical scholarly, introverted Continental law professor. The "repetitor," who prepares young lawyers for their practical examinations, is often a brilliant man whose legal honoratoires are courts. He is conversant with the latest decision and will often display a somewhat sarcastic attitude toward professors and legal theory in general.

22 The second part of Merryman's study of the Italian style seems to me to be an excellent model for orientational comparative literature. See Merryman, The Italian Style II: Laze, 18 StAN. L. REv. 396 (1966). 
over, I am not at all convinced that much more cannot be done by way of mapping various fields of American law in an organized and coherent fashion attuned to European cognitive needs. Often much more may be safely generalized than is usually thought possible. ${ }^{23}$

A very useful device for initiating the Continental student into differences of organization and conceptual technique might be to compare the contents of standard European and American treatises. As an illustration, imagine that civil procedure is involved. Going over the contents of a Continental text, the mentor could briefly explain that an American book on civil procedure will contain no comparable discussion of sources, jurisdiction and competence, or standing, no discussion of evidence, and so forth. He might point out, when necessary, which Continental topics have no equivalent in American law and which are found in other fields. After a number of sessions devoted to this kind of discussion, the student will gain some understanding of the "conversion formulae" in his field. At this early stage he will also obtain some feeling for the limitations inherent in any attempt to translate legal grammar from one legal system to another. A number of illustrations may provide an early awareness of the differences in legal argument and of the typical communication problems in legal discussion.

At this point let me explain an ostensible contradiction. Most people would probably agree that a Continental student will become fully adjusted only after he has learned how to think in the American legal idiom rather than attempting to "translate" Continental into American law. Then why should help be offered with the conversion formulae and panoramic view in the Continental fashion? Are we not prolonging rather than shortening the adjustment period? It is my belief that the attempt to "literally" translate from one system into another is, at least in the initial stages, a cognitive need one cannot obviate. Whatever information on a point of American law the foreign lawyer is given, he will want to relate it to what he already knows in his own legal system. To put it in more abstract terms, one cannot-as a lawyer-study foreign law without legal comparison. And the Continental will, whether one likes it or not, begin by comparing concepts and legal doctrines. Very few temporary visitors will outgrow this stage and truly go inside American law. Even fewer will realize that mere conceptual and doctrinal comparison, in

23 One could make up a long list of publications which are designed for Continental lawyers but which show little or no awareness of their cognitive needs. There are, however, a few works that respond to the special requirements and interests of the Continental embarking on the study of American law. An outstanding example, although it possibly attempts to cover too broad a field, is R. PARKER, DAs PRIVATRECHT DER VEREINIGTEN STAATEN VON AMIERIK. (1960). 
addition to its limitations, is rather sterile. Thus, in a typical case, adjustment difficulties cannot be eliminated. They can only be reduced, by explaining to the student the clash between his expectations and what he can be offered, by satisfying his cognitive needs, and by indicating-as the process goes along-which Continental attitudes must be discarded if the student is truly to go inside the foreign legal system.

Does all this mean that I am pessimistic about the usefulness to Continental lawyers of relatively short exposures to the study of American law in the law schools in this country? The answer turns on what the expectations of the foreign lawyer are. If he expects to learn about American law in his field, learn it in the way in which he would the corresponding field of law in a Continental school, then I must be pessimistic. I also have some doubts that he will ever truly understand how it is that American lawyers manage to operate successfully in their system. But, on the other hand, it seems to me that even brief contacts with American legal education will afford the Continental lawyer many new insights. Most of them will originate in the American approach to legal problems. Probably for the first time, the Continental will become aware-on a plane less exalted than the jurisprudential - of where the limits of useful generalization lie and where the dangers of conceptualism lurk. Another spectrum will be visible to the European lawyer as a result of specific insights into how rigid classification can prevent a lawyer from following a social problem to its satisfactory conclusion. The Continental will become more sensitive to discrepancies between the printed word of the law and its actual practice. Perhaps most important, he will learn the art of-and develop an hospitable attitude towards-the functional integration of related disciplines into a number of legal fields. What the grammatical sophistication of Continental law fears as a threat to its purity, the open and flexible American system welcomes as a contribution.

Thus it is not improbable that many Continental lawyers, comfortably back in their natural legal habitat, will suddenly discover an infection by, as well as an affection for, that strange, never fully understood system of law which caused them so much trouble when they attempted to master it. May I thus close by referring you to André Maurois's thought expressed in the motto?

Nous ne nous sommes pas faits, comme des notes de musique les uns pour les autres parce que différents? 